\title{
THE PRECARIOUSNESS OF PUBLIC HEALTH: ON TUBERCULOSIS CONTROL IN CONTEMPORARY FRANCE
}

\author{
Janina Kehr
}

Accepted Manuscript: "The Precariousness of Public Health: On Tuberculosis Control in Contemporary France." Medical Anthropology 35, no. 5 (September 2, 2016): 377-89. https://doi.org/10.1080/01459740.2015.1091819.

Through an ethnographic exploration of tuberculosis control in one of France's poorest regions, Seine-Saint-Denis, I interrogate the relationships between public health planning and interventions in conditions of multiple precarity. I show that the encounter between the feasible and the fantastic in the realm of public health generates feelings of absurdity and futility among medical professionals, characteristic of disease control in the precarious present. Precarity is neither a social and economic condition per se, nor is the link between disease and precarity static. It is a dynamic process of political inclusions, exclusions and inequalities, which differ substantially within the unequal spheres of precarious lives. The contradictions in tuberculosis control that I describe are thus not only characteristic of French public health, but of global public health today, where illusions in disease control encounter the exclusionary realities of social life.

Keywords: France, global health, migration, precarity, tuberculosis

Running title: Precariousness of Public Health

Media Teaser: Tuberculosis control in France reveals the frictions and absurdities that arise when illusions of ultimate disease control encounter the exclusionary realities of precarious lives. 
On a cold and rainy day in December 2010, just before Christmas, about 50 people gathered in a starkly lit assembly room of a French regional government building, a few kilometers north of Paris, in Seine-Saint-Denis. The building was hidden between worn-down department stores, multi-level parking stations, and busy highways. The participants included community doctors and nurses, local public health officials, and representatives of NGOs, like the French NGO Médecins du Monde (Doctors of the World), who had been invited to reflect on and discuss a public health issue which much of the French population would no longer consider to be a problem in France - Tuberculosis (TB). Sitting on grey plastic chairs in neat rows, the audience listened to the passionate speakers on the podium, three women and one man, who were giving a PowerPoint Presentation on one priority of the local 'fight against tuberculosis' (la lutte contre la tuberculose), the systematic screening of 'precarious populations'. "Why should we actively screen for tuberculosis in our Doctor of the World health center?" one panelist, a physician in her $60 \mathrm{~s}$, asked rhetorically, and immediately answered: "Because our patients' social profiles comprise all the conditions for tuberculosis. Our patients are migrants from high incidence countries and they suffer from extreme poverty, poor health, identity controls, insecurity and everyday harassment." Just a few minutes before, a colleague and co-panelist of hers, the public health officer responsible for local tuberculosis control, Carmen, announced that systematic screenings were a priority in the French National TB Program (Comité national d'élaboration du programme de lutte contre la tuberculose 2007), but had rarely taken place. She furthermore explained that in high-risk regions, such as the one in which she was working, it was not sufficient to wait until people come to the health center once they are sick. Rather, one must screen actively those who one "just knows" to be at risk.

Rhetorical questions and matters of fact, public health imperatives and local knowledge, severe precarity and idealist interventions - such is the edifice of the arguments 
the panelists were making in their presentation of the newly initiated local plan to fight tuberculosis in one of the poorest regions of France, oftentimes referred to in French media as a particular "site of ethnic tribalism, dysfunction and disorder" (Silverstein 2004:120). In this region, Seine-Saint-Denis, high incidence figures for tuberculosis (Antoine and Che 2010) indicate a solid presxence of this "disease without a future" (Kehr 2012) - an infectious disease now primarily associated with immigrants, the elsewhere, or the past in France and other countries of the North (Bashford 2010; Ho 2004; King 2003; Kehr 2012).

Here, I am concerned with the systematic screening of high-risk populations in SeineSaint-Denis, where an old public health intervention, active screening for tuberculosis, is newly planned and put to practice in a location characterized by multiple forms of precarity. Through which forms of knowledge and evidence is this public health intervention planned? How is it then put to practice or actualized? And how are the planning and actualization sides of public health traversed by severe forms of precarity and exclusionary policies, thereby leading to what my research participants described as completely "absurd" situations?

Through exploring active TB screenings in Seine-Saint-Denis, I show the absurdities that the encounter between "the feasible and the fantastic" (Rees 2014:458) generates in the domain of public health. Tuberculosis is globally recognized as a disease of poverty and inequality. Precarity is thus paramount in tuberculosis control, not only in Southern countries, but also in the global North. Yet in France, a republican welfare state construed on an ideal or a fantasy - of equality, inclusion and the fight against social exclusion, encounters with extreme conditions of immigrant precarity and leads to absurd situations and felt futility among public health professionals. In France, desires to cure also those whose lives are most precarious are rubbed against the realities of social and political exclusion and discrimination on multiple levels. Tuberculosis control, this social disease, a disease of the Other and the 'elsewhere', in France is a paradigmatic example to analyze the frictions between precarious 
lives and public health planning and interventions in everyday public health practice, oscillating between attempts of inclusion and logics of exclusion, between evidence and experience, surveillance and treatment, a desire for control and a reality where things regularly get out of control. These frictions, fantasies and absurdities are not only characteristic of French public health, but of global public health today, where the production of illusions of disease control encounters the exclusionary realities of social life.

This article is part of a larger project on the governance of tuberculosis in contemporary France and Germany. I conducted ethnographic fieldwork during 2005 and 2010 in tuberculosis prevention centers and hospitals in the Paris region and Berlin. Through a multi-sited ethnography (Marcus 1995), I 'followed' TB as an object into multiple medical sites, in order to understand how this disease is governed, treated and problematized in the global North. My research included a combination of field observations, interviews, and the analysis of written documents and media accounts, including internal working documents, public health guidelines, epidemiological articles, newspaper articles and TV documentaries. In this article, I draw primarily on ethnographic observations of the daily activities of tuberculosis prevention centers in France, informal conversations with patients, physicians, nurses, social workers and public health officers, and in-depth interviews with these research participants. All conversations, interviews and field notes cited in this article were conducted in French and translated by me.

I first sketch out the socio-cultural landscape of TB existence in France, the 'anthropological location' (Gupta and Ferguson 1997) in which screening for tuberculosis takes place. I then interrogate the feasible and the fantastic sides of public health in conditions of precarity as an example of the historical apparatus of tuberculosis control in France. 
THE OTHER DISEASE: TUBERCULOSIS' ANTHROPOLOGICAL LOCATION IN

\section{FRANCE}

In January 2013, a sensational report on Georgian, Russian and Chechen patients with multidrug-resistant tuberculosis, coming to Paris for treatment, was published in the French conservative newspaper Le Figaro. The journalist described Eastern European patients as "flooding" Parisian hospital services with multi-resistant disease, and "contaminating dozens of people on their way." Immigrant patients were depicted as "undisciplined" and as lacking "the medical culture French people have." A "mafia-like filiation" (Mamou 2013) was suggested to explain the arrival of what was actually a handful of desperate patients, whose home countries share a common trait which anthropologist Erin Koch (2013) has described for Georgia: sub-optimal public health services and treatment access for those ill with "freemarket tuberculosis"- that is, a multi-resistant form of TB that increasingly developed after the breakdown of the Soviet Union and the subsequent decline of public health services.

Although instigative articles on tuberculosis are rare in French media, articles and television reports relating tuberculosis with immigration or - more generally - otherness are common. Typically, tuberculosis is reported once a year only in France, on March 24, World TB Day. In such annual standard accounts, tuberculosis is usually depicted as a disease of poor patients in developing countries, and thus it is placed in a context of global health in the South. In short, tuberculosis is always linked to an 'elsewhere'. Tuberculosis is a disease of the Other, as lucidly captured in the words of a TB patient with whom I worked, Rebecca. The well-off secretary and married mother of two young children spoke of the moment of her diagnosis with TB:

She (the radiologist) told me that it was tuberculosis. Voilà. I didn't quite believe her. Because for me, this is a disease which is disappearing ... For me, TB, is 
something you have if you are not vaccinated, and if you are vaccinated, you don't have it ... So for me, what is it, this disease? It's an old disease. For me, it's really something that starts to disappear, because one talks less and less about it. ... Tuberculosis, it's a strange disease (une maladie étrangère), a disease that I didn't suspect at all. For me, it's a vaccine that you get when you are a kid, and that's it. That's all. Finished. It's one of these diseases, you get a vaccine, you don't get it. It's really, like I already said before, a disease of the middle ages. Dirt, I don't know, tramps, bad hygiene, and all the rest of it. Famines, you know, all these little things, but not today, not in the environment we live. We eat well how to tell you - we don't live in poverty, we are not, you see, all these things, which make this disease happen ... If we were, I don't know, in Africa, then - ok (là, je veux bien). Because over there, you get TB with all these other diseases ... But not here, not in France (Rebecca, white secretary, married with two children, lives in Paris, interview transcript, October 13, 2006).

In Rebecca's account, tuberculosis is an unexpected disease, even an improbable one for her. Rebecca characterized tuberculosis as an "old disease," a "disease of the middle ages," a disease controlled by a medical technology - vaccination. ${ }^{1}$ It is also a "strange disease" to her, a disease of Africa, a disease of poverty "disappearing" from France and the environment in which she lives. In sum, TB is a disease which shouldn't exist anymore, which she shouldn't have, given that she lives in an environment where there is - at least in her imaginary - no poverty, no dirt, no backwardness. Yet Rebecca was diagnosed with this other disease - a fundamentally troubling experience for her.

Rebecca's words show that tuberculosis is systematically related to an 'elsewhere'. This elsewhere is not only the result of nationality and origin - Africa, immigrants - but also temporal - the middle ages, the past - and social - poverty. This cultural image is 
accompanied by little political and scientific interest in the disease; there are relatively few clinical studies or medical evidence production on tuberculosis in France, standard epidemiological accounts of national disease surveillance aside. Anne, the head physician of a French office for tuberculosis control, commented on the absence of novel studies in this field:

Nobody is interested in tuberculosis. For AIDS, there are lots of protocols, there is progress, there are studies. For tuberculosis, there are no studies, there is nothing. You know the article from 1963 you gave me about contact tracing? We are still doing this. This is unbelievable, isn't it? In 50 years, there will still be no studies. It is political will that is lacking. There is no mobilization, either from scientists or from pharmaceutical laboratories (Anne, TB physician, field note transcript, March 12, 2009).

Anne's account might appear slightly exaggerated when one takes into account the global situation of research on TB treatment (Craddock 2012) and diagnostics (Engel 2012), where there has been an increase in novel research initiatives since the early 2000 s, that is, a decade after "the return of the white plague" (Gandy and Zumla 2003) and the announcement of a global TB emergency. Nevertheless, Anne reflects the views of many doctors and nurses working in French tuberculosis control, with whom I engaged during fieldwork, both of the absence of medical interest in TB in France, and the connotation of French TB control with the Old: something that has not substantially changed during the last decades, something that lacks innovation, in contrast to other, more contemporary fields of medicine. Daily, public health professionals working in TB control are thus confronted with little professional recognition due to the low-tech and old nature of their public health interventions, and to much ignorance concerning their treatment and prevention activities from large parts of the French population. 
In reference to Akil Gupta and James Ferguson (1997), I want to term this specific problematization of TB in France and other Western European contexts the disease's 'anthropological location': in Western Europe in the 2000s, TB is only thinkable as a disease of the Other, linked to an elsewhere, either temporal or geographic. And it is a social disease without a future, linked to poverty, time-worn low-tech public health interventions like contact-tracing, mass x-rays and isolation, outside of contemporary biomedical interests, described as increasingly future oriented and technoscientific (Clarke et al. 2003; Jain and Kaufman 2011). As anthropologist Paul Draus has argued, TB is "boring from a medical point of view" (2004:59), and socially overdetermined. It is a "social disease" (Barnes 1995), archetypical of inequalities. Through this vacillation between the medical and the social, past and present, here and elsewhere, and low public and professional recognition, TB screening of high-risk groups in Seine-Saint-Denis takes place. Local crises of tuberculosis among migrants are thereby addressed through old public health strategies like mass screenings with mobile x-ray units, which are reconditioned in the present to get the disease under control, again.

\section{GETTING TUBERCULOSIS UNDER CONTROL, AGAIN}

Seine-Saint-Denis has the highest TB incidence in France, as shown by epidemiological figures annually provided by the French Institute for Public Health Surveillance (InVS). ${ }^{2}$ The region is marked by poverty, economic immigration and deteriorating living conditions, all risk factors linked epidemiologically to TB in France as elsewhere (Antoine 2006; Gandy and Zumla 2003; Ho 2004; Kehr 2009; Story and Citron 2003). In an online documentary by France's center-left newspaper Libération, the physician working for Doctors of the World, already cited in the introduction, summarized this link: “As Seine-Saint-Denis is France's poorest region, it is obvious (évident) that there is a particularly high TB incidence here" 
(Bourgneuf 2014). Chronic conditions of poverty and inequality logically lead to heightened numbers of cases of tuberculosis, ${ }^{3}$ and can quickly get out of control. In 2009 , a local TB crisis occurred, and public health officers feared they would lose control if no supplementary measures were taken:

At one point, we were completely drowned. So we had to issue an emergency call to the State to tell them that we are loosing control ... At this occasion, the State asked us what we would need in order to decrease the TB incidence ... Because at that time, we were in a situation where we had been registering a stable TB incidence in Seine-Saint-Denis for years, it didn't change, it didn't decline, while everywhere else in France it did ... So we set up a working group with the people of the ministry ... To get supplementary funding, we had to propose several new lines of action, which we did ... Finally we got the money to realise two lines of action : the screening of migrant housing facilities and the screening of extremely precarious populations (Carmen, TB physician, interview transcript, December 6, 2010).

Carmen, the public health officer responsible for TB prevention in Seine-Saint-Denis, recounted that during this local TB crisis, when they were overwhelmed with screenings, they were able to get supplementary funding by the French Ministry of Health to plan and implement new pro-active public health measures - the screening of migrant housing facilities and the screening of precarious populations - to get tuberculosis under control, again. In short, Carmen provided a new plan to control an old disease, a plan intended to help reduce the stagnating TB incidence.

In a recent article on AIDS prevention and planning in the field of global health, Tobias Rees showed that such plans are a "distinctly modern form" (2014:458) of practice. Planning as a modern enterprise is thus closely linked to the fields of science and statecraft, of 
which public health is part. Rees writes: "To plan is to come up with a rationally thoughtthrough scheme of action for how to achieve a particular objective. Its realization, which often involves technical measures, is overseen with administrative and bureaucratic accuracy" (2014: 458). In other words, plans and planning are modern projects for action, which depend on administrative and technological knowledge. For Rees, these characteristics of plans document "the fantastic, dreamy side of modernity" (458), the modern desire or utopia to be able to change the present and the future though planning. Planning thus always "oscillates between the feasible and the fantastic" (458), the realistic and the wishful, in the domain of public health as elsewhere.

Much of this could be said of the example of TB control in France, for its history and its present alike, where the dream to free the population from tuberculosis through medical and bureaucratic interventions informed the establishment of an extensive TB control enterprise at the beginning of the twentieth century that is still functioning today. ${ }^{4}$ Back then, TB was seen as a "national scourge, highly contagious, lurking around every corner" (Barnes 1995:13). An extensive plan to control and even eradicate TB, indeed an 'apparatus' in Michel Foucault's sense (1994), was established as a national response to what was an urgent need to 'fight' the omnipresent infection. Foucault defines an apparatus, or dispositif, as "a thoroughly heterogeneous ensemble consisting of discourses, institutions, architectural forms, regulatory decisions, laws, administrative measures, scientific statements, philosophical, moral and philanthropic propositions" (1994:229). The TB control apparatus set up in the early 1900s was such a heterogeneous and far-reaching ensemble: it ranged from public dispensaries - the first one was opened by Albert Calmette in Lille in 1901 - to sanitary offices, sanatoria, isolation rooms in public hospitals, and later mobile x-ray units. It encompassed contact tracing and mass screenings, social housing, distribution of food packages, educational measures, prevention campaigns, patient isolation, and home visits by 
nurses. From the early 1950s, these measures were supplemented with powerful antibiotics, and the dream of tuberculosis eradication became more graspable than ever. Also, TB eradication was increasingly thought of as a medical problem independent of social conditions, as large scale studies among the urban poor in British India seemed to demonstrate through Randomized Controlled Trials (Amrith 2004). In the late 1960s and 1970s, continuously declining numbers of TB patients in France, and the massive uptake of antibiotic combination therapy, spurred confidence in ultimate disease control. ${ }^{5}$ The plan to decrease and eventually eradicate tuberculosis in France involved not only social, administrative and medical interventions, but also faith in the possibility of disease control across populations through public health interventions.

For over a century now, TB control has been a mixture of large-scale public health plans and eradication fantasies in France and elsewhere. The TB control plans and prevention activities of today are thus a legacy of what James Scott calls the high modernist enterprise of planning and public health engineering, which hinged on the "administrative ordering of nature and society" as well as on an ideology of "strong ... self-confidence about scientific and technical progress ... the growing satisfaction of human needs, the mastery of nature" (1998:4). Yet as Scott shows, this ideology, with its heyday in the 1970s when the end of TB seemed to be near, oftentimes fails, as do ambitious public health planning and engineering projects. Tuberculosis control is no exception. Yet there remains a strong belief in the feasibility of efficient TB control and disease elimination for all through public health interventions, if only the economic means and scientific and political engagements are sufficient. This desire for TB control to work is constantly challenged by its failures, and in France, strong faith in medical solutions through providing access to health care for all conflicts with continuing social and political forms of exclusion and discrimination of postcolonial immigrants, “today’s proletarians” (Balibar 2003:50) 


\section{THE FEASIBLE: LOCAL KNOWLEDGE, LONG TERM RELATIONS AND MINIMAL}

\section{STABILITY}

In 2009, the Office for TB Control (Centre de lutte anti-tuberculose, CLAT) in Seine-SaintDenis elaborated a plan to pro-actively decrease TB incidence in the region, by proposing several axes of intervention. The National Ministry of Health saw two axes of intervention as a priority to control $\mathrm{TB}$, and so financed their realization: the systematic screening of people living in Seine-Saint-Denis' migrant housing facilities, and the active screening of so-called 'precarious populations'. The regional Office for TB Control hired a project leader to work in close collaboration with the control teams on the ground, that is, social workers and nurses who had been working in this area for years. The project leader, Elsa, hired on a one-year contract, was just about to finish a master's degree in public health and epidemiology. A trained economist and political scientist, she had been working in the field of humanitarianism in Africa for several years before returning to France.

In numerous conversations, Elsa complained to me that there was no evidence of active screening of high-risk groups in France. Even more so, she criticized the absence of studies on the effectiveness of such interventions:

There are recommendations to screen high risk populations, yes, but that's all that exists. But we don't have any comparative data, no numbers, we don't know whether we will find many cases or not. We have the feeling that we do, but in terms of comparative data, we don't really know (Elsa, public health consultant, field note transcript, November 11, 2010).

Like the public health physician Anne, who had commented on the lack of new research and evidence on TB control, Elsa inscribed her task of intervention planning as difficult. Given that TB is represented as an uninteresting other disease in France, the absence 
of quantitative evidence is oftentimes interpreted as absence of evidence tout court (Ecks 2008:78). National epidemiological data defines general risk groups for tuberculosis in France - undocumented immigrants from sub-Saharan Africa, Roma, homeless people, others living in precarity - but how to make use of this information in public health interventions is left to the prevention centers. Carmen and Elsa thus supplemented general epidemiological knowledge of high risk groups with their own local evidence in order to plan, carry out and evaluate targeted screenings.

To screen collective migrant housing facilities, whose inhabitants are primarily working immigrants from northern and sub-Saharan Africa, Elsa and Carmen set up a priority plan through different forms of local knowledge, long term experience and small scale epidemiology. Carmen and Elsa applied a system of triage to the 60 housing estates in the region, based on criteria of number of inhabitants, room size, number of beds in a room, TB cases during the last years, and geographical origin of the inhabitants. Studies of regional TB epidemiology retrieved through a mandatory declaration system and produced by the local council - a system of administrative disease surveillance (Fearnley 2010) - complemented the housing information. Such annual disease surveillance studies, produced by the epidemiologist of Seine-Saint-Denis' Bureau of Health, gave information on TB cases diagnosed within the estates, and global TB statistics on the TB incidence of those countries from where the immigrants originated, were included in the triage criteria. In sum, Carmen and Elsa conceived of and used these criteria to target particular estates and so set up their screening plan. Such public, statistical knowledge is indispensable for state administration and public health apparatuses to function; it makes public health plans and interventions possible (Desrosieres 2000; Fearnley 2010; Foucault 2004). Yet such epidemiological knowledge is not the only knowledge necessary. The "experientially known" - as Carmen expressed it - is necessary, too, despite that this knowledge is far less valorized and visible in 
"the pursuit of measurable results" (Best 2012:84), particularly in the domain of medicine and public health (Timmermans and Berg 2003).

As Carmen underlined on several occasions, she and Elsa "knew" through prior interventions and long term relations with those living in the housing facilities "what the situation is like;" they knew about the "sociology of the estates." Experiential knowledge on "unofficial housing" or "unofficial room sharing" allowed them to conceive of "invisible" habitants, non-registered day-sleepers, and additional mattresses hidden under bunk beds, in order to develop a hierarchy of disease risk:

It's because of our experience ... Since the beginnings the criteria were quite clear for us. If you talk to Elsa, you will see that she will confirm that the criteria we imagined quite empirically, quite intuitively, voilà, it works, in the reality it really works (Carmen, TB physician, interview transcript, December 6, 2010).

For Carmen and Elsa, the plan worked not least because of their experience, and thus their ability to ask the right questions and produce useful numbers. Figures on cases screened, positives found, treatment completed and contacts defined during the screenings functioned as a reality check after the bureaucratic planning: they confirmed that the screening plan was working. They showed that the fantastic side of the intervention plan, to target and efficiently screen those most at risk, was feasible, not least due to practical knowledge and long-term relations with people living in the housing estates:

Intervening in the housing estates is easy, I am tempted to say. The yield is not huge, but there is a yield. (She laughs). That's why we have to continue the housing estates. It's a population with whom we are used to work. We have long working relations with the people living in the housing estates. We don't have a lot of difficulties; we have no problems of treatment adherence. It just works out (Carmen). 
Empirical knowledge, long term working relations with migrants living in the estates, and local experience made the screening plan work and so the wishful feasible. In his seminal work on large-scale state planning and intervention Seeing like a State, James Scott (1998) conceives of such experience or empirical, practical knowledge, alongside with quantification and standardization, as local knowledge. For Scott, such local knowledge is an indispensable tool of state administration and plan making, in its effort of social engineering and the provision of public health care. Yet it is not only the use and production of different kinds of knowledge that makes the screening plan a success in the eyes of the public health workers. It is also the fact that the treatment of those diagnosed with TB was possible. There were no "problems with treatment adherence," as Carmen expressed it. TB treatment could be organized practically for all inhabitants of the estates, including undocumented migrants, Roma and those without health insurance. Through a specific public insurance scheme, the State Medical Aid (Aide medical d'Etat), hospitalization and treatment follow-up for undocumented immigrants diagnosed with TB is possible in the French public health system. Through this scheme, created in the 1980s, the French state provides minimal medical and legal security for undocumented migrants who are sick (Izambert 2010; Ticktin 2006). The sick body becomes the reason for minimal care and minimal legal stability ${ }^{6}$ in living conditions that are otherwise defined by multiple forms of exclusion and precarity that make TB prosper - overcrowded housing, precarious work, precarious legal status, the absence of political rights, economic dispossession. The fight against TB is thus a symptomatic treatment of a social disease; it does not cure the underlying social and political precarities that allow TB to prosper. But it does treat those sickened by it to keep the disease under control, turning the fantastic side of public health into a feasible one.

Ann Allison has recently illustrated in Precarious Japan that not all forms of precarity are equal, rather, it is "differentially distributed" (2013:9). This is the case in France, where 
'precarity' refers to quite different forms of instability and vulnerability which do not affect the relations between life and disease in the same way. An undocumented immigrant from Mali in a housing estate lives precarity differently than a poor white worker from France, who lives it differently than a Romanian Roma, not least because of different bureaucratic, legal and political regimes of interaction. The relation between precarity, tuberculosis and public health are not the same for all people, nor are their chances of cure the same. In some cases, as I have described, the chances of cure are quite high. In conditions of 'massive precarity' and the absence of a legal apparatus as the State Medical Aid, as I now show for TB screenings for Romanian Roma, ${ }^{7}$ the chances of cure are much lower. In such situations, the wishful side of the screening plan, curing all patients diagnosed with TB to control the disease fails.

THE FAILED FANTASTIC: MASSIVE PRECARITY, POLITICAL CONTRADICTIONS AND TOTAL ABSURDITY

The second part of the TB control plan, screening 'precarious populations', was put to work in collaboration with an NGO, Doctors of the World (DOW). Practically, a mobile x-ray unit - that is, a van equipped with a technician, a secretary, a TB physician, an x-ray machine, a changing room and limited office space - is parked twice a month behind the DOW health center to provide TB screenings free of charge for the centers' patients. In Seine-Saint-Denis, DOW has maintained a permanent medical center since 2004. Here, poor people without health insurance, primarily Romanian Roma and undocumented immigrants from Africa and South Asia, receive basic medical care. Carmen commented that DOW's patients lived in conditions “one cannot even imagine." They “don't have a home, live in the street, live here and there, just arrived in France, don't talk French, don't have any social security, voilà" (Interview transcript, December 6, 2010). When she proposed to DOW in 2010 to collaborate 
to screen and treat these most destitute people, expectations on both sides were high and the wish to make a real difference was strong. The voluntary DOW physician said:

For years we have longed for active TB screening of our patients, but we could not come up with a solution. And then the miracle in 2010, the office for TB control proposed a collaboration. And it was not only to say to our patients: hey, you have TB and good-bye. We also jointly developed a collaboration with the district hospital in order to put them on treatment (DOW Physician, conference transcript, December 15, 2010).

The DOW doctor praised the collaboration between the NGO and the Office for TB Control as a "miracle." She talked about it as a much longed for "solution" to enable preventive TB screenings and early treatment. Her tone was passionate. The words she used allude to the fantastic and the religious: there was "longing," there was a "miracle." In DOW's anticipation, the TB screening plan was the miraculous answer to a very real public health problem, high incidence of disease among the NGO's patients. The TB plan aimed to cure those without health insurance before they suffered from more severe forms of disease due to lack of access to medical care.

Yet once in place, the collaboration led to a rather disillusioning outcome, as statistics produced showed. Despite collaborations with mediators, the district hospital and social workers, most patients who started antibiotic treatment were not able to finish their 6 month treatment program for cure. In all cases these were Roma patients. Ten of 300 Roma patients were discovered to have active TB as a result of the screening plan, but only one of the ten was cured. The outcome of the other nine was unknown, but what was known was that they could not have completed the treatment in France, because they had had to leave the country: immigration authorities had expelled them or members of their families. 
The impossibility of curing Roma patients diagnosed with TB was what Carmen termed the big "failure" of their TB control plan, in which her team, DOW and the Ministry of Health had placed great expectations. The collaboration with DOW, imagined as a "solution" to TB control among "precarious populations", created new, complicated medical and public health problems. The reasons for the failure were clearly "political." At the inception of the TB Control Plan, Carmen explained, immigration authorities promised not to deport Roma patients in treatment and to maintain residential rights for families living in the same "camps" as people diagnosed with TB. However, immigration authorities did not comply with this promise, and patients under treatment received a so-called OQTF (Obligation de quitter le territoire français, obligation to leave the French territory) - an administrative measure of deportation. Patients had to leave the country within a few weeks, and so were unable to finish their six-months treatment in France, a consequence that Lorenzo Alunni has called, in the Italian context, the "fragmentation of ... therapeutic paths" (2015:147).

The social and political context for Roma remains problematic. Roma communities have been the object of "strict securitarian policies" (Alunni 2015:139) over the last decade, and France is no exception. In summer 2011, Nicolas Sarkozy, then French president, announced in his infamous "Speech of Grenoble" a policy of "massive expulsions" for Roma, a policy harshly denounced in public by DOW for its devastating public health effects (Médecins du Monde 2011). Studies about life in Roma communities and their institutional 'management' in France have shown that it is not the mobile lives of Roma that lead to extreme forms of marginalization, but their forced mobility through different apparatuses of bureaucratic and institutional management (Nacu 2010). Carmen and her colleagues were part of such state apparatuses, and yet criticized them. A failure to cure diagnosed Roma patients despite treatment availability did not make any sense for them; it was simply 'absurd': 
We did all we could. Mediators went to the hospitals to see the patients, they accompanied the patients during their consultations, they talked to them and more. And despite our efforts, when there is a demand to expel, all this is useless ... It's terrible. The problem is, well, it's just disastrous; we are just incapable of curing them. We did not think that we would be in that much difficulty. If we would have known before that we would diagnose people we are then unable to treat, really we did not think that it could be that difficult. This is frightening, isnt't it? Massive precarity and we are in the realm of the absurd, we are totally in the realm of the absurd here (Carmen, TB physician, interview transcript, December $6,2010)$.

TB control became a practical impossibility in the reigning political environment of Roma expulsion and discrimination, and public health workers found themselves in the realm of the absurd. For Carmen and her colleagues, absurdity was a direct consequence of "the political contradiction between screening and expelling," a consequence of the incompatibility between two contradictory policy demands in France: sanitary inclusion based on humanitarian arguments versus political and social exclusion of Roma communities. It was an absurd assemblage of "compassion and repression" (Fassin 2005).

Absurd literally means stupid, foolish or unreasonable. In using the term absurd, Carmen described the futilities she felt and the meaninglessness of their public health intervention against an immigration apparatus based on a politics of exclusion. In her works on the Danish Labor welfare system, anthropologist Nina Vohnsen (2011) sketches an anthropology of the absurd in public services and policy making. Vohnsen shows that it is not so that "the situations that provoke the sentiments of absurdity and meaninglessness are characterized by an absence of meaning or logic, but rather a presence of competing goals and conflicting purposes, and a multiplicity of parameters by which to judge the sensibility of 
one's actions" (2011:29). In other words, it is not that there is no logic or systematicity to absurdity in a state's conflicting policies, but rather, absurdity emerges when there is incongruence and friction between different political logics.

In my example, the competing logics between disease control through inclusion on the one side and the expulsion of those sickened by it on the other leads to experiential absurdity among health care workers, and to meaningless measures of TB control. TB control became impossible in the conditions of massive precarity to which Roma communities are subject. In the realm of public health, absurdity emerges when an ideal of disease control through sanitary inclusion rubs against the actualities of political exclusion. The failed fantastic thereby leads to sentiments of meaninglessness and futility that are evocative of public health in the precarious present, far beyond TB control, and far beyond the global North.

\section{CONCLUSION}

Tuberculosis in France today is an immigrants' disease. It mainly emerges in places and among people where multiple forms of precarity co-exist and interact. It is a social disease of Others. This cultural location, I have illustrated, influences the contemporary fight against TB in Seine-Saint-Denis, and so does the historic legacy of French TB control, based on a century old public health apparatus where techno-administrative interventions interact with social and political concerns. This old form of TB control is newly planned, conceived of and actualized in the present in order to target those most at risk for disease today. The desire to control TB among the most precarious and marginalized parts of the population is upheld by an ideal to cure disease independently of the social and political living conditions of the patient, an ideal that is not always feasible and that produces failures to cure. In France, republican values of equality and inclusion are "proclaimed more than respected" (Fassin 2015:7). Precarity and inequality are themselves states of being which are not supposed to exist in the welfare state. 
And yet they do. Social diseases such as tuberculosis are not supposed to exist in a public health care state whose raison d'être is to eliminate them. And yet TB continues to flourish in exactly those localities in which the public health care state acts. The old apparatus of TB control is thus a signifier for the absurdities and failures of public health in the present.

Analyzing these ethnographically allows us to "provincialize forms of precarity" (Muehlebach 2013:298). As I have shown, different forms of precarity and exclusion emerge at the intersection of conflicting regimes of care and control in France: those of immigration and public health policies. In my examples, minimal stability for undocumented immigrants from sub-Saharan Africa made the TB control plan seem feasible, and yet this coexisted with treatment failure for people from Roma communities. Treating Roma, these "pariahs of France" (Médecins du Monde 2011) as DOW has called them, was a utopian ideal rather than a feasible plan to cure disease. In their situation, even the most "minimal biopolitics" (Redfield 2013:18) - to treat diseases in situations of crisis through humanitarian modes of care - fail.

What, then, is the difference between the absurdities and failures I have described for Roma care and the failures of disease control in a context of public health in the global South, the context in which TB is primarily associated today? In spaces of the global South, similar 'disaster regimes' of planning and intervention, as public humanitarian partnerships, mobile intervention units and exceptional conditions of care, are newly assembled within an old public health apparatus to control infectious disease. Yet in global health, in the North and in the South, public health plans are easily subverted, undermined and contaminated by dire political realities that - under conditions of massive precarity - render them meaningless. Tuberculosis control among precarious populations in the global North is but one facet of the field of global health and its multiple absurdities, where North/South divides do not easily hold, and neither do plans with the best intentions. 


\section{ACKNOWLEDGMENTS}

The research at the origin of this article was funded from the Berlin Funding for Graduates (NaFöG) from 2006 to 2010 while I was based at IRIS - Ecole des hautes etudes en sciences sociales Paris and the Institute for European Ethnology at the Humboldt University Berlin. I would like to thank Charlotte Brives, Frederic Le Marcis and Emilia Sanabria for having invited me to write this article. Many thanks also to Carlo Caduff and Kaushik Sunder-Rajan for inspiring conversations and the anonymous reviewers of Medical Anthropology for their valuable comments and suggestions. I am especially grateful to my $\mathrm{PhD}$ advisor, Stefan Beck, who left this world unexpectedly on March 26, 2015, when I was writing this article.

\section{NOTES}

${ }^{1}$ In France, vaccination against tuberculosis through the BCG vaccine was obligatory until 2007 and provided free of charge through local offices for TB control or the national security system. After several expert commissions and reports between 2004 and 2006, the vaccine obligation was suspended in 2007, yet until today, the BCG vaccine is recommended for children at high-risk. For a discussion on BCG vaccination policies in France see (Torny 2007).

2 Annual disease surveillance statistics on tuberculosis are available on the website of France's Institut de Veille Sanitaire, http://www.invs.sante.fr/.

${ }^{3}$ Seeing poverty as the main cause for high numbers of TB has a long tradition in France. It constitutes a more than a century old medical evidence, which is still very much alive and taken-for-granted among those working in TB control today: tuberculosis is a "social disease" (Barnes 1995), it is an archetypical disease of inequalities. Where there is poverty and inequality, there is TB. Only that of today, TB patients in France are not only poor, they are 
poor and immigrants, from Africa, Asia or Eastern Europe. Tuberculosis is a social disease of Others.

${ }^{4}$ Due to this long history reaching up to the present, TB control in France and other European countries is quite different from TB control in sub-Saharan Africa, China, India or former USSR countries, the new "hot spots" of tuberculosis today. In these places, TB control relies primarily on the World Health Organization's DOTS strategy (Directly Observed Treatment Short Course) and thus focuses on the standardized pharmaceutical treatment of symptomatic TB cases. In France though, TB control is not only concerned with treating symptomatic cases. It is also concerned with the active finding of those not yet symptomatic, through active screening of risk-groups or through tracing the contacts of infectious cases (Broekmans et al. 2002). Rather than locating my research in a framework of DOTS and standardized treatment and detection, which has been studied by anthropologists in different world regions (Harper 2006; Harper 2010; Koch 2011; Koch 2013; Ogden, Walt, and Lush 2003), I view it as an adaptation of a historical apparatus of disease control and eradication to a new social and political situation (Kehr 2011).

5 This continues on a global scale today, with a recent statement by the Director of the WHO Stop TB Programme advocating the elimination of tuberculosis from 2015 onwards in 30 low-burden countries, including France (World Health Organization 2014).

${ }^{6}$ Didier Fassin has analyzed this phenomenen as « biolegitimacy », where the sick body gives political rights to otherwise politically unrecognized and rightless people (Fassin 2001).

${ }^{7}$ I use the term Roma as it is used by my research participants in the field, that is as a label which refers primarily to Roma from Romania, most of them living either slum areas or camps in Seine-Saint-Denis. Despite the fact that Romanian Roma are EU-citizens and theoretically have the right to circulate freely among the EU member states, within 
restrictions that apply to Romanian and Bulgarian citizens, this right is not applied in France, where Roma are expelled due to a measure called Obligation to Leave the French Territory. Especially in 2010, the year of my fieldwork, a particularly harsh and illegal expulsion policy was applied (Groud 2013; Willsher 2010).

\section{REFERENCES}

Allison, A.

2013 Precarious Japan. Durham, NC, and London: Duke University Press.

Alunni, L.

2015 Securitarian healing: Roma mobility and health care in Rome. Medical Anthropology 34(2): 139-149.

Amrith, S.

2004 In search of a 'magic bullet' for tuberculosis: South India and beyond, 1955-

1965. Social History of Medicine 17(1): 113-130.

Antoine, D.

2006 Tuberculose et migrations internationales en Europe de l'Ouest. PhD

Dissertation, Démographie, Université Paris X Nanterre.

Antoine, D. and D. Che

2010 Epidemiologie de la tuberculose en France: Bilan des cas déclarés en 2008.

Bulletin Epidémiologique Hebdomadaire(27-28): 289-293.

Balibar, E.

2003 We, the People of Europe? Reflections on Transnational Citizenship. Princeton, NJ: Princeton University Press. 
Barnes, D.

1995 The Making of a Social Disease: Tuberculosis in Ninenteenth-Century France. Berkeley, CA: University of California Press.

Bashford, A.

2010 The great white plague turns alien: Tuberculosis and immigration in Australia, 1901-2001. In Tuberculosis Then and Now. Perspectives on the History of an Infectious Disease. F. Condrau and M. Worboys, eds. Pp. 100-122. Montreal, QC and Kingston, ON: McGill-Queen's University Press.

Best, J.

2012 Bureaucratic ambiguity. Economy and Society 41(1): 84-106.

Bourgneuf, C.

2014 Tuberculose, MST : La Seine-Saint-Denis n'a plus d'argent pour dépister. http://www.liberation.fr. http://www.liberation.fr/video/2014/09/03/tuberculosemst-la-seine-saint-denis-n-a-plus-d-argent-pour-depister_1092866

Broekmans, J.F., G.B. Migliori, H.L. Rieder, et al.

2002 European Framework for Tuberculosis Control and Elimination in Countries with a Low Incidence: Recommendations of the World Health Organization (WHO), International Union Against Tuberculosis and Lung Disease (IUATLD) and Royal Netherlands Tuberculosis Association (KNCV) Working Group. European Respiratory Journal 19(4): 765-775.

Clarke, A.E., J.K. Shim, L. Mamo, J. Ruth Fosket, and J. R. Fishman

2003 Biomedicalization: technoscientific transformations of health, illness, and U.S. biomedicine. American Sociological Review 68(2): 161-194.

Comité national d'élaboration du programme de lutte contre la tuberculose 
2007 Programme de Lutte contre la tuberculose en France 2007-2009. Paris: Ministère de la Santé, de la Jeunesse et des Sports.

Craddock, S.

2012 Drug partnerships and global practices. Health \& Place 18(3): 481-489.

Desrosieres, A.

2000 La Politique des Grands Nombres. Histoire de la Raison Statistique. Paris: La Découverte.

Draus, $\mathrm{P}$.

2004 Consumed in the City: Observing Tuberculosis at Century's End. Philadelphia, PA: Temple University Press.

Ecks, S.

2008 Three propositions for an evidence-based medical anthropology. Journal of the Royal Anthropological Institute 14: S77-S92.

Engel, N.

2012 New diagnostics for multi-drug resistant tuberculosis in India: Innovating control and controlling innovation. BioSocieties 7(1): 50-71.

Fassin, D.

2001 The biopolitics of otherness. Anthropology Today 17(1): 3-7.

2005 Compassion and repression: The moral economy of immigration policies in France. Cultural Anthropology 20(3): 362-387.

2015 In the name of the Republic: Untimely meditations on the aftermath of the Charlie Hebdo attack. Anthropology Today 31(2): 3-7. 
Fearnley, L.

2010 Epidemic intelligence. Langmuir and the birth of disease surveillance.

Behemoth. A Journal on Civilisation 3(3): 36-56.

Foucault, M.

1994 Dits et écrits : Tome III, 1976-1979. Paris: Gallimard.

2004 Sécurité, Territoire, Population : Cours au Collège de France. 1977-1978. Paris: Seuil.

Gandy, M. and A. Zumla, eds

2003 The Return of the White Plague : Global Poverty and the "New" Tuberculosis. London: Verso.

Groud, T. H.

2013 Citoyenneté et mobilité en Europe. Plein Droit 99(4): 21-24.Gupta, A. and J. Ferguson, eds

1997 Anthropological Locations. Boundaries and Locations of a Field Science.

Berkeley, CA: University of California Press.

Harper, I.

2006 Anthropology, Dots and understanding tuberculosis control in Nepal. Journal of Biosocial Science 38(1): 57-67.

2010 Extreme conditions, extreme measures? Compliance, drug resistance, and the control of tuberculosis. Anthropology \& Medicine 17(2): 201.

Ho, M.-J.

2004 Sociocultural aspects of tuberculosis: A literature review and a case study of 
immigrant tuberculosis. Social Science \& Medicine 59(4): 753-62.

Izambert, C.

201030 Ans de régressions dans l'accès aux soins. Plein Droit (86): 5-8.

Jain, S. L. and S. R. Kaufman, eds

2011 Introduction. After progress: Time and improbable futures in clinic spaces.

Medical Anthropology Quarterly 25(2): 183-188.

King, N. B.

2003 Immigration, race and geographies of difference in the tuberculosis pandemic. In

Return of the White Plague. Global Poverty and the New Tuberculosis. M.

Gandy and A. Zumla, eds. Pp. 39-54. London: Verso Press.

Kehr, J.

2009 The politics and poetics of migrant tuberculosis: Modelling a 'social disease' in French public health. In The Tapestry of Health, Illness and Disease, V.

Kalitzkus and P. L. Twohig, eds. Pp. 99-124. Amsterdam: Rodopi.

2011 L'épaisseur des vies sociales. A propos du dépistage de la tuberculose. In De la Vie Biologique à la Vie Sociale. Approches Sociologiques et Anthropologiques,

J. Vailly, J. Kehr, and J. Niewöhner, eds. Pp. 268-97. Paris: La Découverte.

2012 Une maladie sans avenir. Anthropologie de la tuberculose en France et en Allemagne". PhD dissertation, Department of Social Anthropology and Ethnology, Ecole des hautes études en sciences sociales, Paris.

2012 Blind spots and adverse conditions of care: Screening migrants for tuberculosis 
in France and Germany. Sociology of Health \& Illness 34 (2): 251-65.

Koch, E.

2011 Local microbiologies of tuberculosis: Insights from the republic of Georgia. Medical Anthropology 30(1): 81.

2013 Free Market Tuberculosis: Managing Epidemics in Post-Soviet Georgia. Nashville, TN: Vanderbilt University Press.

Mamou, Y.

2013 Des hôpitaux débordés par des tuberculeux d'Europe de l'Est. Le Figaro, January 23.

Marcus, G. E.

1995 Ethnography in/of the world-system. The emergence of multi-sited ethnography. Annual Review of Anthropology 24: 95-117.

Médecins du Monde

2011 Dossier de Presse. Parias: Les Rroms En France.

Muehlebach, A.

2013 On precariousness and the ethical imagination: The year 2012 in sociocultural anthropology. American Anthropologist 115(2): 297-311.

Nacu, A.

2010 Les Roms migrants en région parisienne : Les dispositifs d'une marginalisation. Revue européenne des migrations internationales 26(1): 141-160.

Ogden, J., G. Walt, and L. Lush

2003 The politics of "branding" in policy transfer: The case of dots for tuberculosis control. Social Science \& Medicine 57(1): 179-88. 
Redfield, P.

2013 Life in Crisis: The Ethical Journey of Doctors Without Borders. Berkeley, CA: University of California Press.

Rees, T.

2014 Humanity/Plan; Or, On the "stateless" today (Also being an anthropology of global health). Cultural Anthropology 29(3): 457-478.

Scott, J. C.

1998 Seeing like a State: How Certain Schemes to Improve the Human Condition Have Failed. New Haven, CT: Yale University Press.

Silverstein, P. A.

2004 Algeria in France: Transpolitics, Race, and Nation. Bloomington, IN: Indiana University Press.

Story, A. and K. Citron

2003 Private wealth and public squalor: The resurgence of tuberculosis in London. In The Return of the White Plague. Global Poverty and the New Tuberculosis. M. Gandy and A. Zumla, eds. Pp. 147-162. London: Verso.

Ticktin, $\mathrm{M}$.

2006 Where ethics and politics meet: The violence of humanitarianism in France. American Ethnologist 33(1): 33-49.

Timmermans, S. and M. Berg

2003 The Gold Standard: The Challenge of Evidence-Based Medicine and Standardization in Health Care. Philadelphia, PA: Temple University Press. Torny, D.

2007 De L'établissement de l'obligation vaccinale aux annonces de sa levée : Une 
analyse sociologique des controverses et polémiques autour Du BCG (19472006). In Rapport sur le levée de l'obligation vaccinale par le BCG chez les enfants. Synthèse et recommandations de l'audition publique des 13 et 14 novembre 2006 Pp. 190-199. Vandoeuvre-les-Nancy: Société Française de Santé Publique.

Vohnsen, N.

2011 Absurdity and the sensible decision. Implementation of Danish labour market policy. PhD Dissertation, Section for Anthropology and Ethnology, Aarhus University.

Willsher, K.

2010 France's deportation of Roma shown to be illegal in leaked memo, say critics. The Guardian. http://www.guardian.co.uk/world/2010/sep/13/francedeportation-roma-illegal-memo.

World Health Organization

2014 WHO Targets Elimination of TB in over 30 Countries. WHO. http://www.who.int/mediacentre/news/releases/2014/tb-elimination/en/. 